\title{
A Routine Activity Approach: Assessing Victimization by Gender in Transit Environments and Other Public Locations
}

\author{
Dennis M. Savard \\ Department of Criminal Justice, Saginaw Valley State University, University Center, Michigan, USA \\ Email: dmsavard@svsu.edu
}

How to cite this paper: Savard, D. M. (2018). A Routine Activity Approach: Assessing Victimization by Gender in Transit Environments and Other Public Locations. Advances in Applied Sociology, 8, 56-75. https://doi.org/10.4236/aasoci.2018.81004

Received: November 28, 2017

Accepted: January 16, 2018

Published: January 19, 2018

Copyright $\odot 2018$ by author and Scientific Research Publishing Inc. This work is licensed under the Creative Commons Attribution International License (CC BY 4.0).

http://creativecommons.org/licenses/by/4.0/

\section{(c) (i) Open Access}

\begin{abstract}
The purpose of this research is to examine how transit environments and other public spaces shape women's and men's victimization for simple assault, aggravated assault, sexual assault, robbery, and kidnapping crimes. This research applies routine activities theory to examine how everyday activities shape victimization within these environments. Using data from the Federal Bureau of Investigations' 2014 National Incident-Based Reporting System, this research finds that women were more likely to be victimized in certain spaces such as shopping centers and transit terminals. Regarding certain violent crimes, it was also discovered that women were more likely to be robbed at shopping centers, grocery stores, parking lots/garages, and transit terminals. It is argued that understanding the vulnerability of simple assault, aggravated assault, sexual assault, robbery, and kidnapping victimization women have in transit environments and other public spaces may provide useful insight regarding preventing crime in these locations.
\end{abstract}

\section{Keywords}

Gender Gap in Crime, Gender, Transit Environments, Public Spaces, Routine Activity Theory

\section{Introduction}

Except for sexual assaults, it is a truism that men suffer more violent victimizations than women. Consequently, social scientists have neglected gender as a variable of importance in the study of violent crime (Zimring, 2006). The result has been criminological and victimological research taking on an androcentric tone that placed importance on men and overlooked crime against women (Cook, 
2016). However, more recent research (Lauritsen \& Rezey, 2013) acknowledges the gendered nature of victimization (Gartner, 1990; Marvell \& Moody, 1999; Smith \& Brewer, 1992; Smith \& Brewer, 1995). Specifically, recent studies have been conducted on the long-term trends of male and female homicide victimization (Batton, 2004; Browne \& Williams, 1993; Pizarro, et al., 2010; Pridemore \& Freilich, 2005) as well as non-lethal victimization. To date, most studies that have examined the gender gap in crime have focused on the long-term trends in male and female victimization (Langton, et al., 2013). Indeed, this important body of work has showed that the gender gap in crime is closing regarding victimization, most notably for aggravated and simple assaults (Lauritsen \& Heimer 2008).

The aim of this study is to examine the victimization of women in transit environments and other public spaces that are often found near transit environments, and how the gender gap in victimization is affected within these spaces. This is done by comparing 1) the types of crime women are targets of; 2) the types of public spaces women experience victimization; and 3) how transit environments and public spaces shape victimization for women. The present study uses data from the Federal Bureau of Investigation by examining the victimization of women within transit environments and public spaces, and will fill in the gap of past research that examined the trends in victimization of women and men. Routine activity theory will be used to explain how transit environments and public spaces shape victimization differently for women and men in terms of vulnerability to victimization. This study will explore how victimization varies within transit environments and public spaces often found adjacent to transit stops, and the types of crime women are victims of in these environments.

\section{Routine Activity Theory}

Routine activities theory (RAT) is an influential perspective criminologists use to study what makes it possible for a criminal event to occur. Cohen and Felson (1979) explain that there are three necessary conditions for a crime to occur. Specifically, crimes occur when a motivated offender, a suitable target, and the lack of a capable guardian come together in time and space. Environmental and land-use features may influence a motivated offender to victimize a woman in a parking lot with a connected bus stop (Loukaitou-Sideris, 1999).

The term "suitable target" was purposefully chosen by Cohen and Felson (1979) rather than "victim" because they wanted to include property as targets of crime, in addition to people. The term "capable guardian" was chosen over police because informal guardians such as members of the public can also provide guardianship. Therefore, bystanders who happen to be around when the crime is being committed can be more effective capable guardians than the police, insofar as they are present when the crime takes place (Savard, Kelley, \& Merolla, 2017).

An important aspect of RAT regards the convergence of the three concepts described above in time and space. This convergence occurs in the routine activities of people as they go about their lives. Therefore, much of crime is a mun- 
dane phenomenon that occurs during everyday life, rather than in exciting and abnormal circumstances. Cohen and Felson (1979) argued that predatory type crimes were increasing in the United States in post-World War II because people were venturing out of the household more, and leaving property unattended, unlike in past time periods.

\section{Research on Transit Environments and Other Public Spaces}

The American Public Transportation Association in 2015 reported that 653 U.S. public transportation systems operated buses in urban environments and 525 operated buses in rural areas. Undoubtedly, many of the routes taken by these buses had stops at or near shopping malls, grocery stores, universities, and parking lots/garages. This same association reports that for the third of Americans who resided in rural communities, public transportation was vital for them in terms of having access to education, shopping, entertainment, and employment. In fact, it was reported that $12 \%$ of public transportation users (e.g., bus riders) in 2013 used public transportation to get to and from school, such as a university. In other words, public transit users may have to rely solely on public transportation thereby rendering them "transit captives" because they have no other means of traveling when performing routine activities. Because females have been identified as using public transit at higher rates (Yu \& Smith, 2014), they may have a higher risk of victimization in transit environments based on offenders' perceptions of vulnerability and target suitability. The nexus of perceived vulnerabilities with transit environments in areas experiencing social disorganization (Shaw \& McKay, 1972) can exacerbate an already increased risk of victimization. It may be that women are more vulnerable to victimization based on perpetrators' perceptions of women being a "suitable target."Female robbers, for example, have been found to purposely target female victims because they view them as more vulnerable and least likely to resist (Miller, 1998).

Some universities have bus lines dedicated to the thousands of university students, faculty, and staff to relieve crowding and reduce parking costs. The American Public Transportation Association (2007) also reports that strategically placing residential and commercial development near public transportation is a growing practice. This practice is referred to as Transit-Oriented Development where housing, shopping, educational institutions, and employment are within reasonable walking distance to public transportation. Indeed, practices such as these coalesce shopping centers, grocery stores, universities, and parking lots/ garages with transit environments. This is important because research has shown a concentration of bus stops can have an impact on the overall crime rate in the surrounding area (Kooi, 2013). Research has also found that some public locations such as schools (Roman, 2005), parking lots (Laycock \& Austin, 1992), and shopping malls (Brantingham et al., 1990; Savard \& Kennedy, 2014) can have an impact on the overall crime rate for adjacent public spaces.

Transit environments and public spaces, such as bus stops, shopping centers and grocery stores, can provide for the coming together of a motivated offender, 
suitable target, and lack of a capable of guardian where the motivated offender may not be deterred because of his or her rationalizations of the number of victims and the likelihood of not being apprehended for lack of capable guardians. Public locations may serve as a "critical intensity zone" wherein there are enough suitable targets to attract motivated offenders but not enough capable guardians to deter them (Angel, 1968; Block \& Block, 2000). The bystander effect and a desire for anonymity by citizens may also contribute to the victimization of suitable targets in public spaces (Chekroun \& Brauer, 2002). Fear of crime in these settings can influence the routine activities of people as well (Ceccato, 2016; Ceccato, 2014; Loukaitou-Sideris, 2014; Madan \& Nalla, 2016; Wiebe, et al., 2014). In addition to this fear of crime, people may expect to experience an unpleasant event, such as observing a suicide on train tracks, while using the services of a railway station (Shibata, et al., 2014). Transit environments within public spaces can also serve as crime generators (Brantingham \& Brantingham, 1995). Crime generators are spaces offenders are attracted to, but do not have inherent criminogenic characteristics. Therefore, transit environments situated in or adjacent to certain public spaces can attract potential perpetrators.

Transit environments may also foster offenders' journey to crime (Phillips, 1980), but research has found little support that public transportation introduces non-residential offenders to new hunting grounds (Sedelmaier, 2014). Crime attractors, on the other hand, produce crime in and of themselves because of the nature of their environment. Therefore, bus stops located near crime attracting environments such as bars, vacant/abandoned buildings, and derelict motels can contribute to a criminogenic environment where people are waiting for buses and consequently victimized (Loukaitou-Sideris, 1999). Because street robberies can cluster in time and space and occur in high traffic areas such as transit terminals (Glasner \& Leitner, 2016) and areas surrounding bus stops have been identified as having higher rates of violent victimizations (Block \& Davis, 1996; Caplan, et al., 2012), the concept of near-repeat victimization based on the closeness transit environments have to high risk locations can exacerbate an already criminogenic environment that are "risky facilities" to begin with (Clarke \& Eck, 2007).

However, research has identified a higher likelihood of robbery victimization when a bus stop is located near an ATM compared to only an ATM, but a lower risk of robbery victimization when a bus stop is located near a bar compared to only a bar (Hart \& Miethe, 2014). Robbers tend to commit robberies in places that fall within their routine travels and are close to their homes. The idea is that robbers are not only more comfortable with operating in places they routinely travel, but they may be aware of security measures meant to stop them before a robbery is committed or apprehend them after a robbery is committed. Therefore, not only will robbers rationally choose to prey upon women because of their perceived vulnerable state, but will rationally pick an area close to their home because this increases their chances of successfully victimizing women and decreases their chances of being caught (Wright \& Decker, 1997). Certainly, the 
number of women and men who occupy any one location needs to be considered when examining the situational contexts of criminal victimization, but perceived vulnerabilities from the perspective of the perpetrator can start to explain why women may be more likely to be victimized in transit environments.

\section{Gendered Nature of Spaces}

Gender expectations and the femininity and masculinity attached to gender help produce the creation of gendered spaces such as the workplace and community (Spain, 1992). It is not so much a gendered space by its very nature as it is considered a gendered space based on the feminine and masculine behaviors performed by women and men. In other words, behaviors at grocery stores and shopping malls are influenced by ideas of femininity and masculinity and what it means to be a woman or man. As people go about their routine activities throughout the day, they travel to and visit places which are designated spaces for men and women. Gender is intimately tied to society and has a profound impact on how males and females act in particular social contexts. Therefore, shopping for clothes or groceries has feminine and masculine qualities attached to them. Gendered spaces are dependent upon what society says is appropriate behavior for women and men and this determines if the behaviors performed at each respective location are considered feminine or masculine. Societal expectations as they relate to gender heavily influence individuals' routine activities. In turn, broad social structural patterns influence violent victimization. For example, macro-historical events and how women and men come to occupy certain spaces in society can explain how victimization is place based and translates into potential dangerous spaces. Specifically, women occupy these spaces because of structural forces and historical influences, and consequently may be at a particular risk of criminal victimization in such spaces. However, the increased risk of victimization is not linked to the behaviors being performed in each respective gendered space; rather, it may be that women are more vulnerable to victimization based on perpetrators' perceptions of women being a "suitable target."It could be the gendered nature of grocery stores and shopping centers that contribute to the number of women and men who occupy them where the preponderance of women and men occupying such spaces place them at an increased risk of victimization based on vulnerability (Savard, Kelley, \& Merolla, 2017).

\section{Hypotheses}

Hypothesis 1: It is expected that females will be more likely than males to be victimized in transit terminals, shopping centers, grocery stores, parking lot/garages, and universities.

Hypothesis 2: It is expected that females will be more likely than males to be the victim of a simple assault in transit terminals, shopping centers, grocery stores, parking lot/garages, and universities.

Hypothesis 3: It is expected that females will be more likely than males to be 
the victim of an aggravated assault in transit terminals, shopping centers, grocery stores, parking lot/garages, and universities.

Hypothesis 4: It is expected that females will be more likely than males to be the victim of a robbery in transit terminals, shopping centers, grocery stores, parking lot/garages, and universities.

\section{Data and Methods}

The present study will use data from the National Incident-Based Reporting System (NIBRS) for the year 2014. Unlike the Uniform Crime Reporting System (UCR) which collects data at the aggregate level, the NIBRS collects incidentlevel data. Furthermore, the NIBRS expands the level of collection by including 46 Group A Offenses, whereas the level of collection by the UCR only includes eight Index offenses (Addington, 2007). A major advantage of the NIBRS is that the victim type is identified (i.e., individual or business) and victims' demographic information is also collected. The location of where the incident occurred is also collected in the NIBRS.

The purpose for conducting this project is to analyze data of simple assaults, aggravated assaults, robberies, sexual assaults, and kidnappings that occur in transit terminals and other public locations. A major goal of this study is to examine if the study variable locations are related to the gender gap in victimizations. For example, there were 451,712 simple assaults, 93,606 aggravated assaults, 44,395 sexual assaults, 21,378 robberies, and 8935 kidnappings reported in the 2014 NIBRS data. Of these numbers, females represented $65.1 \%$ of simple assault victims, $49.4 \%$ of aggravated assault victims, $86.9 \%$ of sexual assault victims, $33.6 \%$ of robbery victims, and $83.9 \%$ of kidnapping victims. Notwithstanding simple assaults, sexual assaults, and kidnappings, more men than women were aggravated assault and robbery victims. This research project will hypothesize that the likelihood of female victimization will be greater when examined in the context of transit environments and other public locations.

\section{Measures}

\subsection{Dependent Variable}

All of the variables in the study will include a series of dummy variables. Gender will represent the one dependent variable in this study. Gender will be coded as a dummy variable, with males coded as 0 and females coded as 1 . Unfortunately, the data does not allow for examining other gender categories, such as transgendered individuals. The use of female as a dependent variable is not to predict gender. The study is using characteristics of a crime to discover the likelihood that the victim is male or female. ${ }^{1}$

\footnotetext{
${ }^{1}$ Each case in the data represents a criminal incident. The gender variable in the dataset represents a person who was either a female victim or male victim. Therefore, within a given incident, the models are examining what the likelihood is that the victim is female or male. The models are not predicting their gender. For example, if one could imagine a large silo that contains crime victims, what would be the likelihood that we would pull out a female victim or male victim?
} 


\subsection{Independent Variables}

Target suitability will be operationalized using the victim's age and time of day. Age of victim was coded into four separate dummy variables: 18 - 29, $30-49,50$ - 64, and 65+. The reference category will be victims 17 years of age and younger. Time of day was coded into three separate dummy variables: 7 a.m. to 11 a.m., 12 p.m. to 4 p.m., and 5 p.m. to 11 p.m. The reference category will be 12 a.m. to 6 a.m.

Perceptions that a victim or a law enforcement officer has regarding if an offender was using alcohol or drugs will be used to operationalize offender motivation. Routine activity theory assumes that offenders are rational beings who weigh the costs relative to the benefits before committing a crime. Therefore, an offender not under the influence of alcohol or drugs may be more effective in terms of evaluating the presence of capable guardians, particularly in public locations. Motivated offenders not inhibited by alcohol or drug use may be more likely to seek out environments where a pool of suitable targets is available. It is predicted that offenders who are under the influence of alcohol or drugs will be less likely to commit crimes against women.

Guardianship will be operationalized using one indicator, where the incident took place. NIBRS provides a comprehensive list of locations where criminal events took place. ${ }^{2}$ Five public locations will be examined: grocery stores, shopping centers, parking lots, universities, and transit terminals. Location will include five dummy variables: grocery store $(0=\mathrm{No}, 1=\mathrm{Yes})$, shopping center $(0$ $=$ No, $1=$ Yes $)$, parking lot $(0=$ No, $1=$ Yes $)$, university $(0=$ No, $1=\mathrm{Yes})$ and transit terminal $(0=$ No, $1=$ Yes $)$. Notwithstanding transit terminals, the location variables were chosen to be included in the analysis because it is not uncommon to find transit terminals, such as bus stops, located at or adjacent to them.

There will be a number of control variables in the study, along with a number of interactions. The victim's race will be a control measure by using two dummy variables, black and white, with other race serving as the reference category. The relationship that the victim has with the perpetrator will include three dummy variables: stranger, intimate partner, and acquaintance. The reference category will be other family. There will be a total of five crimes that will be examined in this study: simple assault $(0=\mathrm{No}, 1=\mathrm{Yes})$, aggravated assault $(0=\mathrm{No}, 1=\mathrm{Yes})$, robbery $(0=$ No, $1=$ Yes $)$, sexual assault $(0=$ No, $1=$ Yes $)$, and kidnapping $(0=$ No, $1=$ Yes). There is a total of four values that will be used to constitute the sexual assault variable.

${ }^{2}$ There are many locations identified in NIBRS data. These locations include but are not limited to: 1) home; 2) bank; 3) bar; 4) alley; 5) church; 6) prison; and 7) playground. In addition to transit terminals, I chose shopping centers, grocery stores, parking lot/garages, and universities as study variables because of the number of bus stops that are located at or near these locations. For example, it is not uncommon for local municipalities to have ordinances/laws that require private properties give access to public transportation (see Center for Urban Transportation Research, (2009), Public Transit Access to Private Property, January 2009.). 


\section{Analytic Strategy}

Logistic regression will be the statistical technique utilized in this research project. The Statistical Package for the Social Sciences (SPSS) will be used for all analyses. Logistic regression is the preferred statistical technique when dependent variables are categorical in nature. As was described above, the dependent variable in this study is dichotomous. Because the dependent variable is comprised of two categories, the quantitative data will be analyzed using logistic regression. When the dependent variable is dichotomous and not continuous in nature, the logistic regression model allows for estimations of the coefficient that measure the effect predictor variables have on an outcome variable (Bachman \& Paternoster, 2009). Pearson's correlation coefficients were used a priori to examine potential issues of multicollinearity.

\section{Results}

Table 1 presents the descriptive statistics for the study variables. Interestingly, over half of the crime victims in the study were women. It might be expected that men would have a higher percentage of criminal victimization in the dataset based on ideas of victimization and who is more likely to be victimized, but the NIBRS reports that more women than men are victims of crime. However, it is important to point out that men are still more likely to suffer violent acts of crime, such as robbery and aggravated assaults. A possible reason for this disparity in crime victimization rates is that the NIBRS is a different measure of crime and reports more different types of crime when compared to the UCR, so this might serve as an explanation as to why more women are victims of crime in the NIBRS.

The variables measuring target suitability includes victim's age, the time of day in which the crime occurred, and if the offender was perceived to have been under the influence of alcohol and/or drugs. A not insignificant number of crimes were perpetrated against individuals in the different age categories. Specifically, $34.1 \%$ of crime victims were between 18 - 29 years of age, $36.8 \%$ were between 30 - 49 years of age, $11.8 \%$ were between 50 - 64 years of age, and approximately $2.3 \%$ were $65+$ years of age. With respect to the first two age categories, these results are not surprising findings because these age categories are more likely to visit places outside of the home when compared to other age categories. Also, it may be that people in these age ranges are more likely to travel outside of the home. Criminals may view women as suitable targets not just because they are alone when visiting places outside of the home, but because they are viewed as more vulnerable and therefore unable to thwart any predatory attacks, such as a sexual assault. $16.2 \%$ of the crime victimizations occurred from 7 a.m. to 11 a.m., $24.4 \%$ occurred from 12 p.m. to 4 p.m., and $39.6 \%$ occurred from 5 p.m. to 11 p.m., respectively.

The locations used in the present study to measure guardianship had a relatively low base rate. In other words, both women and men are more likely to be 
Table 1. Means and Standard Deviations for All Study Variables.

\begin{tabular}{|c|c|c|}
\hline & Percentage & $\mathrm{N}$ \\
\hline \multicolumn{3}{|l|}{ Dependent Variable } \\
\hline Female & 63.6 & 743,711 \\
\hline \multicolumn{3}{|l|}{ Independent Variables } \\
\hline \multicolumn{3}{|l|}{ Target Suitability } \\
\hline $18-29(\text { victim age })^{\mathrm{a}}$ & 34.1 & 743,711 \\
\hline $30-49(\text { victim age })^{\mathrm{a}}$ & 36.8 & 743,711 \\
\hline $50-64(\text { victim age })^{\mathrm{a}}$ & 11.8 & 743,711 \\
\hline $65+(\text { victim age })^{\mathrm{a}}$ & 2.3 & 743,711 \\
\hline 7 a.m. to 11 a.m. (time of day) ${ }^{b}$ & 16.2 & 743,711 \\
\hline 12 p.m. to 4 p.m. (time of day) ${ }^{b}$ & 24.4 & 743,711 \\
\hline 5 p.m. to 11 p.m. (time of day) & 39.6 & 743,711 \\
\hline \multicolumn{3}{|l|}{ Offender Motivation } \\
\hline Alcohol and drug use ${ }^{c}$ & 13.5 & 743,711 \\
\hline \multicolumn{3}{|l|}{ Guardianship } \\
\hline Parking lot/garage ${ }^{\mathrm{d}}$ & 3.8 & 743,711 \\
\hline Shopping center ${ }^{\mathrm{d}}$ & 0.57 & 743,711 \\
\hline Grocery store $^{\mathrm{d}}$ & 0.33 & 743,711 \\
\hline Transit terminal $^{\mathrm{d}}$ & 0.29 & 743,711 \\
\hline University $^{\mathrm{d}}$ & 0.32 & 743,711 \\
\hline \multicolumn{3}{|l|}{ Controls } \\
\hline Simple assault & 60.7 & 743,711 \\
\hline Aggravated assault & 12.5 & 743,711 \\
\hline Sexual assault & 5.9 & 743,711 \\
\hline Robbery & 2.8 & 743,711 \\
\hline Kidnapping & 1.2 & 743,711 \\
\hline White victim & 68.4 & 743,711 \\
\hline Black victim & 29.8 & 743,711 \\
\hline Intimate partner & 36.4 & 743,711 \\
\hline Other known & 21.7 & 743,711 \\
\hline Stranger & 9.4 & 743,711 \\
\hline
\end{tabular}

${ }^{\mathrm{a}}$ Reference Category is $<17$ years old; ${ }^{\mathrm{b}}$ Reference category is 11:59 p.m. to 6:59 a.m.; ${ }^{\mathrm{c}}$ Reference Category is non-alcohol and drug use; ${ }^{\mathrm{d}}$ Reference Category is other location.

victimized in other locations. Even with these low base rates, it is still important to examine victimization in these spaces because, as it will be demonstrated below, when individuals are victimized in these locations, it is more likely to involve women with respect to certain situational contexts. 3.8\% of crime occurred at parking lot/garages, $0.57 \%$ of crimes occurred at shopping centers, $0.33 \%$ of 
crime occurred at grocery stores, $0.29 \%$ of crime occurred at transit terminals, and $0.32 \%$ of crime occurred at universities. The first crime type, simple assault, consisted of about $60 \%$ of the total amount of crime. $12.4 \%$ of the sample included aggravated assaults, about $6 \%$ of the sample included sexual assaults, about $3 \%$ of the sample included robberies, and kidnapping made up about $1 \%$ of the sample. When looking at victim's race, about $68 \%$ of the crime victims in the study were white and about $30 \%$ of the sample consisted of black victims. Regarding the nature of the relationship between the victim and perpetrator, about $36 \%$ of the samples were victimized by an intimate partner, about $22 \%$ were victimized by an acquaintance, and about $9 \%$ were victimized by a stranger.

The results of the logistic regression analysis models predicting variation in the likelihood that women will suffer victimization in public spaces is presented in Table 2. First, it was predicted that the indicators of target suitability (time of day and victim's age) would be significantly and positively associated with the likelihood that women would be victimized. In other words, and according to RAT, it would be expected that women would be more likely to be victimized during the morning, afternoon, and evening hours. Furthermore, it would be expected that women in each respective age category would be more likely to be victimized compared to the reference group. According to Model 1, women 18 29 years old, 30 - 49 years old, and 65+ are significantly more likely to be victimized. When a crime occurs between 7 a.m. to 11 a.m. and 12 p.m. to 4 p.m., women are significantly more likely to be the victim of a crime. The indicator used to measure offender motivation was if the offender was perceived to be under the influence of drugs and/or alcohol. The results indicate that women are approximately $8 \%$ less likely to be victimized by an offender who was perceived to be under the influence of alcohol and/or drugs. If women are less likely to be victimized in public locations where the incident can potentially be observed by capable guardians, motivated offenders may view women as suitable targets based on perceptions of vulnerability and choose to commit their crimes while not under the influence because they do not want their mental state to be inhibited. This is not to suggest that women are inherently more vulnerable to victimization compared to men; rather, motivated offenders may perceive them to be vulnerable. Location of the crime was the one indicator used to measure guardianship. Women are significantly more likely to be victimized at shopping centers and transit terminals. However, women are about $17 \%$ less likely to be victimized in a parking lot/garage and are about $11 \%$ less likely to be victimized at a university. No significant findings were discovered for grocery stores. Therefore, Hypothesis 1 was partially supported.

Hypothesis 2 predicts that women will be more likely to suffer a simple assault in the study location variables. These hypotheses were tested using Model 2 of Table 2. According to Model 2, women were less likely to suffer a simple assault at grocery stores, parking lots/garages, and universities. No significant findings were discovered for shopping centers and transit terminals. Therefore, Hypothesis 2 was not supported. 
Table 2. Odds Ratios from Logistic Regression Predicting Female Victimization.

\begin{tabular}{|c|c|c|}
\hline & Model 1 & Model 2 \\
\hline \multicolumn{3}{|l|}{ Age of Victim $(0=<17)$} \\
\hline $18-29$ & $1.81^{\star}(0.008)$ & $1.81^{*}(0.008)$ \\
\hline $30-49$ & $1.42^{*}(0.008)$ & $1.42^{\star}(0.008)$ \\
\hline $50-64$ & $1.00(0.010)$ & $1.00^{*}(0.010)$ \\
\hline $65+$ & $1.13^{*}(0.017)$ & $1.12^{\star}(0.017)$ \\
\hline \multicolumn{3}{|l|}{ Time of Crime $(0=12$ a.m. to 6 a.m. $)$} \\
\hline 7 a.m. to 11 a.m. & $1.08^{*}(0.009)$ & $1.08^{*}(0.009)$ \\
\hline 12 p.m. to 4 p.m. & $1.07^{\star}(0.008)$ & $1.07^{\star}(0.008)$ \\
\hline 5 p.m. to 11 p.m. & $0.991(0.007)$ & $0.990^{*}(0.007)$ \\
\hline \multicolumn{3}{|c|}{ Offender Alcohol and Drug Use $(0=$ no drug and alcohol use $)$} \\
\hline Alcohol and drug use & $0.916^{*}(0.007)$ & $0.915^{\star}(0.007)$ \\
\hline \multicolumn{3}{|l|}{ Location of Crime ( $0=$ other location $)$} \\
\hline Shopping Center & $1.38^{*}(0.034)$ & $1.25^{\star}(0.063)$ \\
\hline Grocery Store & $1.05(0.043)$ & $1.20^{*}(0.083)$ \\
\hline Parking lot/garage & $0.829^{\star}(0.013)$ & $0.713^{*}(0.036)$ \\
\hline University & $0.892^{*}(0.044)$ & $1.22^{\star}(0.089)$ \\
\hline Terminal & $1.11^{\star}(0.047)$ & $0.928(0.135)$ \\
\hline \multicolumn{3}{|l|}{ Race of victim $(0=$ other race $)$} \\
\hline White & $0.821^{\star}(0.020)$ & $0.823^{\star}(0.020)$ \\
\hline Black & $1.08^{\star}(0.020)$ & $1.08^{*}(0.020)$ \\
\hline \multicolumn{3}{|c|}{ Victim/Offender Relationship $(0=$ other family $)$} \\
\hline Intimate partner & $2.87^{\star}(0.006)$ & $2.87^{\star}(0.006)$ \\
\hline Acquaintance & $0.744^{\star}(0.006)$ & $0.745^{\star}(0.006)$ \\
\hline Stranger & $0.382^{\star}(0.009)$ & $0.381^{\star}(0.009)$ \\
\hline \multicolumn{3}{|l|}{ Crime Type $(0=$ other crime $)$} \\
\hline Simple assault & $0.784^{*}(0.007)$ & $0.783^{*}(0.007)$ \\
\hline Aggravated assault & $0.434^{*}(0.009)$ & $0.436^{\star}(0.009)$ \\
\hline Sexual assault & $5.16^{*}(0.016)$ & $5.00^{\star}(0.016)$ \\
\hline Robbery & $0.464^{\star}(0.017)$ & $0.431^{\star}(0.018)$ \\
\hline Kidnapping & $2.43^{*}(0.030)$ & $2.42^{*}(0.031)$ \\
\hline \multicolumn{3}{|l|}{ Location by Crime Type } \\
\hline Shopping center ${ }^{\star}$ simple assault & & $1.09(0.078)$ \\
\hline Shopping center ${ }^{\star}$ aggravated assault & & $0.866(0.141)$ \\
\hline Shopping center ${ }^{\star}$ sexual assault & & $1.81^{\star}(0.273)$ \\
\hline Shopping center ${ }^{\star}$ robbery & & $1.98^{*}(0.132)$ \\
\hline Shopping center kidnapping & & $1.01(0.454)$ \\
\hline
\end{tabular}




\section{Continued}

\begin{tabular}{|c|c|}
\hline Grocery store ${ }^{\star}$ simple assault & $0.745^{\star}(0.102)$ \\
\hline Grocery store ${ }^{\star}$ aggravated assault & $0.631^{\star}(0.177)$ \\
\hline Grocery store ${ }^{\star}$ sexual assault & $2.37^{\star}(0.404)$ \\
\hline Grocery store ${ }^{\star}$ robbery & $1.68^{*}(0.057)$ \\
\hline Grocery store ${ }^{\star}$ kidnapping & $0.348(0.560)$ \\
\hline Parking lot/garage ${ }^{\star}$ simple assault & $0.154^{\star}(0.039)$ \\
\hline Parking lot/garage ${ }^{\star}$ aggravated assault & $0.994(0.050)$ \\
\hline Parking lot/garage ${ }^{*}$ sexual assault & $3.34^{*}(0.139)$ \\
\hline Parking lot/garage ${ }^{\star}$ robbery & $1.68^{*}(0.057)$ \\
\hline Parking lot/garage ${ }^{\star}$ kidnapping & $1.38^{*}(0.148)$ \\
\hline University ${ }^{\star}$ simple assault & $.602^{*}(0.063)$ \\
\hline University ${ }^{*}$ aggravated assault & $.600(0.214)$ \\
\hline University $^{*}$ sexual assault & $1.68^{*}(0.255)$ \\
\hline University* robbery & $0.878(0.339)$ \\
\hline University ${ }^{\star}$ kidnapping & $0.296^{\star}(0.510)$ \\
\hline Terminal $^{*}$ simple assault & $1.60^{*}(0.132)$ \\
\hline Terminal $^{*}$ aggravated assault & $1.20(0.147)$ \\
\hline Terminal $^{*}$ sexual assault & $1.18(0.305)$ \\
\hline Terminal $^{\star}$ robbery & $1.86^{*}(0.184)$ \\
\hline Terminal* kidnapping & $0.433(0.722)$ \\
\hline
\end{tabular}

Note: Standard errors in parentheses; ${ }^{\star} p<0.05$.

Hypothesis 3 predicts females will be significantly more likely to suffer aggravated assault victimizations in each of the study location variables. It was found that women were less likely to suffer aggravated assault victimizations at grocery stores and universities, and no significant findings were discovered for the remaining locations. Therefore, Hypothesis 3 was not supported.

Regarding robbery victimizations, women were significantly more likely to be robbed at shopping centers, grocery stores, parking lots/garages, and transit terminals. Therefore, Hypothesis 4 was mainly supported. With respect to the crime of robbery, this finding supports the study's claim that transit environments and public spaces shape victimization differently for women and men in terms of vulnerability to victimization. Model 1 indicates that there is a strong negative main effect for robbery victimization, but when robberies are examined in the context of shopping centers, grocery stores, parking lots/garages, and transit terminals; we see that the gender gap in robbery victimization flips where women are more likely to be robbed.

\section{Discussion}

The gender gap in crime explains that men and women experience criminal vic- 
timization differently. Crime statistics, particularly those from governmental sources, consistently show that men outnumber women as suffering violent acts of crime. The one exception to this is that women are much more likely to suffer rapes. Men, on the other hand, are more likely to suffer aggravated assaults, robberies, and murder. Researchers have studied trends in the gender gap in crime and observed that this crime gap is starting to close. However, the closing of this gap is the result of men's victimization rates dropping and women's victimization rates remaining stable over time (Lauritsen \& Heimer 2008). The current study investigated this gap in the research by attempting to use the ideas of routine activity theory (RAT) to understand how men and women experience victimization in different situational contexts.

Drawing upon insights from Cohen and Felson (1979), criminal victimization can be explained as occurring during individuals' routine activities as they got about their day, and can further be shaped by the interrelatedness of certain spaces. The idea is that women will be more vulnerable in these spaces because offenders view them as suitable targets. It was found that the odds of women being victimized in some public spaces were greater than men. Individuals' routine activities generally take place in the morning to late evening hours. The results indicate that women were more likely to be victimized during times when people are more active in public locations.

From a practical standpoint, a related perspective associated with RAT is Crime Prevention through Environmental Design (CPTED). The tenets of CPTED can be implemented in an effort to prevent and deter crime from occurring in the study's location variables. This perspective assumes that there is a symbiotic relationship between the environment and human behavior, and manipulating the environment will also alter human behavior (Newman, 1973). Bus stops situated in shopping centers, for example, invoke natural surveillance. Natural surveillance consists of designing the natural environment to allow people to freely overlook a property and have clear sightlines to potentially observe criminal activity. Bus stops located at or near shopping mall parking lots bring people together on a consistent basis at all hours of the day and night, and efficient designs of these locations can go a long way in helping prevent crimes. This is particularly important when considering the study's findings on robbery victimization in public spaces. Hypothesis $4 \mathrm{~A}$-E predicted that women were more likely to be robbed in each of the study's location variables. Model 1 of Table 2 shows a strong negative effect for robbery victimizations, but when robbery is examined in transit environments, for example, women start becoming significantly more likely to be robbery victims.

The interactions of robbery victimization by location show that the difference in this type of crime is smaller in transit terminals, shopping malls, grocery stores, and parking lots/garages. The study predicted that women would have a greater likelihood of suffering robbery victimization in transit environments and other public spaces. Notwithstanding universities, support for using routine ac- 
tivity theory as a theoretical explanation of how women and men experience victimization in transit environments and other public spaces is particularly observed in robbery victimizations.

Oftentimes, large regional shopping centers have enormous parking lots to accommodate the thousands of people who patronize them every day, and consequently the design of these parking lots can create desolate environments. Public transportation can have an iatrogenic effect in that travelers are brought to locations where they can potentially be victimized. Therefore, a woman traversing a shopping mall parking after being dropped off at a bus stop may be victimized by a motivated offender operating with impunity because of a lack of capable guardians. Conversely, it also may be that a motivated offender utilizing public transportation victimizes a shopping mall patron in a parking lot. Indeed, public transportation can influence both victim and offending rates within the context of public locations. Paying attention to lighting, implementing patrolling security guards, and operating CCTV may help with altering human behavior and ultimately prevent crime (Savard \& Kennedy, 2014). However, the effectiveness of lighting may only be good insofar as it prevents specific types of crimes and not crimes in general (Farrington \& Welsh, 2002), whereas the efficacy of patrolling security guards and CCTV regarding their deterrent value have been challenged (Telep \& Weisburd, 2012; Welsh \& Farrington, 2002).

Speaking from the RAT perspective, visiting public spaces occurs during the routine, mundane activities that women and men engage in on an everyday basis. The ideas of RAT were used to examine specific crime type victimizations in public spaces. When the crime of robbery is examined, the results indicate that women have higher odds of robbery victimization in all but one of the public spaces. Women were less likely to suffer robbery victimizations in general, but when looking at the situational dynamics of the crime, women are more likely to be robbed in shopping centers, grocery stores, parking lots/garages, and terminals. Robbers can be rational thinkers when committing their crimes because prior research has found that they target victims who seem vulnerable and do not pose any threats (Felson \& Messner, 1996). The crime selection type of an offender can be critical in terms of preventing crime in public spaces. For example, robbery is generally not a crime type selected at random by an offender. The rational robber will be careful to look for escape routes when evaluating the suitability of a target and guardians who can offer protection. If offenders are rational beings and weigh the costs and benefits before they choose to commit a robbery, security measures such as enhanced lighting and random security patrols may act as a deterrent. A threefold method can be used by increasing the levels of personnel on buses to deter a robbery, having alarms on buses to thwart a robbery, and placing locating systems on buses to apprehend a robbery suspect (Hoel, 1992).

Implementing security measures (e.g., security guards, upgraded lighting, CCTV) within transit environments may help alleviate any inherent risks of vic- 
timization, but some transit environments may be more receptive to security measures in terms of preventing crime. The ideas of prospect, refuge, and escape proposed by Fisher and Nasar (1992) can help explain why crime may be more likely to occur in some transit environments compared to others. Prospect refers to being able to scan a space without obstruction, refuge refers to being able to identify safe harbor, and escape refers to being able to exit a space. Indeed, these concepts have practical implications for the security and safety of transit environments and other public locations. For example, a motivated offender may be able to more effectively surveil a bus stop location, take refuge after committing a crime, and ultimately flee the area more effectively compared to an underground station. In other words, bus stops provide an environment conducive to predation based on the concepts above, whereas underground stations may limit a motivated offender's choices in terms of identifying a suitable target because this environment improves guardianship (Uittenbogaard, 2014). Security practitioners can take advantage of the symbiotic relationship that exists between human behavior and the unique features of some transit environments where security measures may be more effective and guardianship improved (Savard \& Kennedy, 2013). However, risks associated with theft and terrorism (e.g., biological and chemical agents) are always present in underground subway systems because of available targets and the construction of these spaces (Newton, et al., 2014).

In addition to solving specific crime problems in the community through a problem-oriented response (Goldstein, 1990), another tactic grounded within a legal framework is being utilized by law enforcement as a third-party approach. Third party policing is a method where policing agencies and local governments work together to encourage properties that have been deemed a nuisance within the community to address issues of crime (Mazerolle \& Ransley, 2006). For example, law enforcement and local municipal governments can use nuisance abatement laws to force unwillingly problematic properties to deal with issues of crime on their property (O'Connor, 1977). In other words, civil remedies in the form of regulations and statutes can be used as a method of crime prevention (Mazerolle \& Roehl, 1998). Indeed, businesses being threatened with daily fines may be an effective way to motivate them to deal with issues on their properties. Therefore, the use of third party policing can be used for properties adjacent to transportation hubs that are contributing to the overall crime rate in the area by holding "place managers" partially responsible for the criminogenic environment (Eck, 1994; Eck \& Wartell, 1998; Madensen \& Eck, 2008; Mazerolle, et al., 1998; Sampson, et al., 2010). Another area in which third parties can be held accountable for crime on their properties is the use of expert witnesses in civil lawsuits. "Social science in law" can be used as a "social framework" to explain the potential culpability or innocence of a property owner for a criminal victimization that occurred on his or her property (Monahan \& Walker, 1990; Walker \& Monahan, 1987). 


\section{Limitations}

The data used in this study is not without its limitations because it provides limited coverage and consequently is not representative of all police departments across the United States. For example, of the 33 states that reported crime data via the NIBRS in 2014, all law enforcement agencies in 16 of the 33 states submitted their crime data using the NIBRS (FBI, 2014). Even though the NIBRS improves upon the UCR by eliminating the Hierarchy Rule, problems associated with unreported crime or the "dark figure of crime" remains an issue for the NIBRS. Indeed, crime is brought to the attention of the police in two ways, either they observe it themselves or it is brought to their attention by the citizenry. Consequently, issues of validity and reliability can be a problem for crime data that is relied on being reported by law enforcement agencies. Even with these limitations, researchers are starting to utilize and analyze NIBRS data in their research (Savard, Kelley, \& Merolla, 2017; Tillyer \& Tillyer, 2014).

Another limitation of the study is the NIBRS's inability to allow for the identification of a bus stop, for example, at or near a shopping center. Consequently, there is no way to determine if the risk of victimization for women is greater at a bus stop located near a shopping center compared to a stand-alone bus stop located on a city street. It could be that stand-alone bus stops are more dangerous for riders based on their isolation from nearby businesses, such as shopping centers and grocery stores. Future research should distinguish between transit environments located at or near businesses and those that are solitary in nature. NIBRS also does not consider the "environmental backcloth" of transit environments (Brantingham \& Brantingham, 1993). Therefore, future studies should account for the differences between transit environments and public spaces based on their location, history, users, and how security measures are perceived (Savard \& Kennedy, 2014). Examining the unique environmental characteristics of transit environments may allow for a more detailed understanding of victimization risk.

\section{Conclusion}

It is generally accepted among criminological and victimological researchers that men outnumber women as being victims of crime, particularly violent crime. Researchers have started to challenge this generalized thinking by examining the gender differentiated trends in victimization. The study argues that this line of thinking has the potential to allow for a better understanding of the situational dynamics of criminal victimization among the genders. Using the RAT perspective provides a theoretical lens through which the gender gap in crime can be viewed in transit environments. This theory allows for examining how everyday activities of people shape their victimization in transit environments and public spaces. Overall, the study's findings generally supported the perspective that the gender gap in crime is impacted by routine activities within transit environments and the propinquity of public spaces. 


\section{References}

Addington, L. A. (2007). Using NIBRS to Study Methodological Sources of Divergence between the UCR and NCVS. In J. P. Lynch, \& L. A. Addington (Eds.), Understanding Crime Statistics: Revisiting the Divergence of the NCVS and UCR (pp. 225-250). New York, NY: Cambridge University Press.

American Public Transportation Association (2007). Public Transportation: Benefits for the 21st Century.

American Public Transportation Association (2015). Public Transportation Fact Book

Angel, S. (1968). Discouraging Crime through City Planning. Berkley, CA: University of California.

Bachman, R. D., \& Paternoster, R. (2009). Statistics for Criminology and Criminal Justice. London: SAGE Publications.

Batton, C. (2004). Gender Differences in Lethal Violence: Historical Trends in the Relationship between Homicide and Suicide Rates, 1960-2000. Justice Quarterly, 3, 423461. https://doi.org/10.1080/07418820400095861

Block, R., \& Block, C. R. (2000) The Bronx and Chicago: Street Robbery in the Environs of Rapid Transit Stations. In V. Goldsmith et al. (Eds.), Analyzing Crime Patterns: Frontiers in Practice (pp. 137-152). New York, NY: Sage. https://doi.org/10.4135/9781452220369.n11

Block, R., \& Davis, S. (1996). The Environs of Rapid Transit Stations: A Focus for Street Crime or Just Another Risky Place. In R. V. Clarke (Ed.), Preventing Mass Transit Crime (pp. 237-257). Monsey, NY: Criminal Justice Press.

Brantingham, P. L., \& Brantingham, P. J. (1993). Nodes, Paths and Edges: Considerations on the Complexity of Crime and the Physical Environment. Journal of Environmental Psychology, 1, 3-28. https://doi.org/10.1016/S0272-4944(05)80212-9

Brantingham, P. L., Brantingham, P. J., \& Wong, P. (1990). Malls and Crime: A First Look. Security Journal, 3, 175-181.

Brantingham, P., \& Brantingham, P. (1995). Criminality of Place: Crime Generators and Crime Attractors. European Journal on Criminal Policy and Research, 3, 5-26. https://doi.org/10.1007/BF02242925

Browne, A., \& Williams, K. R. (1993). Gender, Intimacy, and Lethal Violence: Trends from 1976 through 1987. Gender \& Society, 7, 8-98.

https://doi.org/10.1177/089124393007001005

Caplan, J. M., Kennedy, L. W., \& Piza, E. L. (2012). Integrating Spatial Crime Analysis Techniques for Tactical Strategies Actions (pp. 1-5). Rutgers Center on Public Security Brief.

Ceccato, V. (2014). Safety on the Move: Crime and Perceived Safety in Transit Environments. Security Journal, 27, 127-131. https://doi.org/10.1057/sj.2014.11

Ceccato, V. (2016). Public Space and the Situational Conditions of Crime and Fear. International Criminal Justice Review, 26, 69-79.

https://doi.org/10.1177/1057567716639099

Chekroun, P., \& Brauer, M. (2002). The Bystander Effect and Social Control Behavior: The Effect of the Presence of Others on People's Reactions to Norm Violations. European Journal of Social Psychology, 32, 853-867. https://doi.org/10.1002/ejsp.126

Clarke, R. V., \& Eck, J. E. (2007). Understanding Risky Facilities: Tool Guide No. 6. Washington DC: Center for Problem-Oriented Policing.

Cohen, L. E., \& Felson, M. (1979). Social Change and Crime Rate Trends: A Routine Ac- 
tivity Approach. American Sociological Review, 44, 588-608. https://doi.org/10.2307/2094589

Cook, K. J. (2016). Has Criminology Awakened from Its “Androcentric Slumber"? Feminist Criminology, 11, 334-353. https://doi.org/10.1177/1557085116660437

Eck, J. E. (1994). Drug Markets and Drug Places: A Case-Control Study of the Spatial Structure of Illicit Drug Dealing. Doctoral Dissertation, Research Directed by Institute of Criminal Justice and Criminology, University of Maryland at College Park.

Eck, J. E., \& Wartell, J. (1998). Improving the Management of Rental Properties with Drug Problems: A Randomized Experiment. Crime Prevention Studies, 9, 161-185.

Farrington, D. P., \& Welsh, B. C. (2002). Effects of Improved Street Lighting on Crime: A Systematic Review. London: Home Office.

Federal Bureau of Investigation (2014). Uniform Crime Reporting Program (UCR): National Incident-Based Reporting System (NIBRS). http://www.fbi.gov/about-us/cjis/ucr/nibrs/2012/resources/nibrs-participation-by-state

Felson, R. B., \& Messner, S. F. (1996). To Kill or Not to Kill? Lethal Outcomes in Injurious Attacks. Criminology, 34, 519-545. https://doi.org/10.1111/j.1745-9125.1996.tb01218.x

Fisher, B. S., \& Nasar, J. L. (1992). Fear of Crime in Relation to Three Exterior Site Features: Prospect, Refuge, and Escape. Environment and Behavior, 24, 35-65. https://doi.org/10.1177/0013916592241002

Gartner, R. (1990). The Victims of Homicide: A Temporal and Cross-National Comparison. American Sociological Review, 55, 92-106. https://doi.org/10.2307/2095705

Glasner, P., \& Leitner, M. (2016). Evaluating the Impact the Weekday Has on Near-Repeat Victimization: A Spatio-Temporal Analysis of Street Robberies in the City of Vienna, Austria. International Journal of Geo-Information, 6, 1-18. https://doi.org/10.3390/ijgi6010003

Goldstein, H. (1990). Problem-Oriented Policing. New York, NY: McGraw-Hill.

Hart, T. C., \& Miethe, T. D. (2014) Street Robbery and Public Bus Stops: A Case Study of Activity Nodes and Situational Risk. Security Journal, 27, 180-193. https://doi.org/10.1057/sj.2014.5

Hoel, L. A. (1992). Public Transportation Security. In G. Gray, \& L. Hoel (Eds.), Public Transportation (pp. 509-524). Englewood Cliffs, NJ: Prentice Hall.

Kooi, B. R. (2013). Assessing the Correlation between Bus Stop Densities and Residential Crime Typologies. Crime Prevention \& Community Safety, 15, 81-105.

https://doi.org/10.1057/cpcs.2012.15

Langton, L., Planty, M., \& Truman, J. (2013). Criminal Victimization, 2012.

Lauritsen, J. L., \& Heimer, K. (2008).The Gender Gap in Violent Victimization, 1973-2004. Journal of Quantitative Criminology, 24, 125-147. https://doi.org/10.1007/s10940-008-9041-y

Lauritsen, J. L., \& Rezey, M. L. (2013). Measuring the Prevalence of Crime with the National Crime Victimization Survey. Washington DC: Bureau of Justice Statistics, US Department of Justice.

Laycock, G., \& Austin, C. (1992). Crime Prevention in Parking Facilities. Security Journal, 3, 154-160.

Loukaitou-Sideris, A. (1999). Hot Spots of Bus Stop Crime: The Importance of Environmental Attributes. Journal of the American Planning Association, 65, 395-411.

https://doi.org/10.1080/01944369908976070 
Loukaitou-Sideris, A. (2014). Fear and Safety in Transit Environments from the Women's Perspective. Security Journal, 27, 242-256. https://doi.org/10.1057/sj.2014.9

Madan, M., \& Nalla, M. K. (2016). Sexual Harassment in Public Spaces: Examining Gender Differences in Perceived Seriousness and Victimization. International Criminal Justice Review, 26, 80-97. https://doi.org/10.1177/1057567716639093

Madensen, T. D., \& Eck, J. E. (2008). Violence in Bars: Exploring the Impact of Place Manager Decision-Making. Crime Prevention \& Community Safety, 10, 111-125. https://doi.org/10.1057/cpcs.2008.2

Marvell, T. B., \& Moody, C. E. (1999). Female and Male Homicide Victimization Rates: Comparing Trends and Regressors. Criminology, 37, 879-902. https://doi.org/10.1111/j.1745-9125.1999.tb00508.x

Mazerolle, L. G., \& Roehl, J. (1998). Civil Remedies and Crime Prevention (Vol. 9). Monsey, NY: Criminal Justice Press.

Mazerolle, L. G., Kadleck, C., \& Roehl, J. (1998). Controlling Drug and Disorder Problems: The Role of Place Managers. Criminology, 36, 371-404. https://doi.org/10.1111/j.1745-9125.1998.tb01252.x

Mazerolle, L., \& Ransley, J. (2006). Third Party Policing. Cambridge: Cambridge University Press. https://doi.org/10.1017/CBO9780511489297

Miller, J. (1998). Up It Up: Gender and the Accomplishment of Street Robbery. Criminology, 36, 37-66. https://doi.org/10.1111/j.1745-9125.1998.tb01239.x

Monahan, J., \& Walker, L. (1990). Social Science in Law: Cases and Materials. Westbury, NY: Foundation Press.

Newman, O. (1973). Defensible Space: Crime Prevention through Urban Design. New York, NY: Collier.

Newton, A. D., Partridge, H., \& Gill, A. (2014). In and Around: Identifying Predictors of Theft within and near to Major Mass Underground Transit Systems. Security Journal, 27, 132-146. https://doi.org/10.1057/sj.2014.2

O'Connor, P. J. (1977). Nuisance Abatement Law as a Solution to New York City's Problem of Illegal Sex Related Businesses in the Mid-Town Area. Fordham Law Review, 46, 57-90.

Phillips, P. D. (1980). Characteristics and Typology of the Journey to Crime. In D. Georges-Abeyie, \& K. Harries (Eds.), Crime: A Spatial Perspective (pp. 156-166). New York, NY: Columbia University Press.

Pizarro, J. M., DeJong, C., \& McGarrell, E. F. (2010). An Examination of the Covariates of Female Homicide Victimization and Offending. Feminist Criminology, 5, 51-72. https://doi.org/10.1177/1557085109354044

Pridemore, W. A., \& Freilich, J. D. (2005). Gender Equity, Traditional Masculine Culture, and Female Homicide Victimization. Journal of Criminal Justice, 33, 213-223. https://doi.org/10.1016/j.jcrimjus.2005.02.002

Roman, C. G. (2005). Routine Activities of Youth and Neighborhood Violence: Spatial Modeling of Place, Time, and Crime. In F. Wang (Ed.), Geographic Information Systems and Crime Analysis (pp. 293-310). Hershey, PA: Idea Group. https://doi.org/10.4018/978-1-59140-453-8.ch017

Sampson, R., Eck, J. E., \& Dunham, J. (2010). Super Controllers and Crime Prevention: A Routine Activity Explanation of Crime Prevention Success and Failure. Security Journal, 23, 37-51. https://doi.org/10.1057/sj.2009.17

Savard, D. M., \& Kennedy, D. B. (2013). Responding to Intimate Partner Violence in the Workplace. Security Journal, 26, 249-263. https://doi.org/10.1057/sj.2013.15 
Savard, D. M., \& Kennedy, D. B. (2014). Crime and Security Liability Concerns at Shopping Centers. In K. Walby, \& R. Lippert (Eds.), Corporate Security in the 21st Century (pp. 254-275). London: Palgrave Macmillan.

Savard, D. M., Kelley, T. M., \& Merolla, D. M. (2017). Routine Activities and Criminal Victimization: The Significance of Gendered Spaces. Journal of Interpersonal Violence. https://doi.org/10.1177/0886260517721170

Sedelmaier, C. M. (2014). Offender-Target Redistribution on a New Public Transport System. Security Journal, 27, 164-179. https://doi.org/10.1057/sj.2014.4

Shaw, C. R., \& McKay, H. D. (1972). Juvenile Delinquency and Urban Areas (Rev. ed.). Chicago, IL: Chicago University Press.

Shibata, S., Hanyu, K., Hata, T. D., \& Yamaoka, Y. (2014). Expectation and Perception of Crime and Disorder Events in Railway Stations in Tokyo. Security Journal, 27, 210-225. https://doi.org/10.1057/sj.2014.7

Smith, M. D., \& Brewer, V. E. (1992). A Sex-Specific Analysis of Correlates of Homicide Victimization in United States Cities. Violence and Victims, 7, 279-286.

Smith, M. D., \& Brewer, V. E. (1995). Female Status and the "Gender Gap" in US Homicide Victimization. Violence against Women, 1, 339-350. https://doi.org/10.1177/1077801295001004003

Spain, D. (1992). Gendered Spaces. Chapel Hill, NC: University of North Carolina Press.

Telep, C. W., \& Weisburd, D. (2012). What Is Known about the Effectiveness of Police Practices in Reducing Crime and Disorder? Police Quarterly, 15, 331-357. https://doi.org/10.1177/1098611112447611

Tillyer, M. S., \& Tillyer, R. (2014). Maybe I Should Do This Alone: A Comparison of Solo and Co-Offending Robbery Outcomes. Justice Quarterly, 32, 1064-1088.

Uittenbogaard, A. C. (2014). Assessing Guardianship Opportunities at Underground Stations. Security Journal, 27, 147-163. https://doi.org/10.1057/sj.2014.3

Walker, L., \& Monahan, J. (1987). Social Frameworks: A New Use of Social Science in Law. Virginia Law Review, 73, 559-598. https://doi.org/10.2307/1072923

Welsh, B. C., \& Farrington, D. P. (2002). Crime Prevention Effects of Closed Circuit Television: A Systematic Review (Vol. 252). London: Home Office.

Wiebe, D. J., Richmond, T. S., Poster, J., Guo, W., Allison, P. D., \& Branas, C. C. (2014). Adolescents' Fears of Violence in Transit Environments during Daily Activities. Security Journal, 27, 226-241. https://doi.org/10.1057/sj.2014.8

Wright, R. T., \& Decker, S. H. (1997). Armed Robbers in Action: Stickups and Street Culture. Boston: Northeastern University Press.

Yu, S. S. V., \& Smith, M. J. (2014). Commuters using Public Transit in New York City: Using Area-Level Data to Identify Neighbourhoods with Vulnerable Riders. Security Journal, 27, 194-209. https://doi.org/10.1057/sj.2014.6

Zimring, W. D. (2006). The Great American Crime Decline. Oxford: Oxford University Press. https://doi.org/10.1093/acprof:oso/9780195181159.001.0001 